\title{
Prospects for Agribusiness Development Sea Cucumbers (Holothuroidea sp) In the province of South Sulawesi, Indonesia
}

\author{
Asriani $^{1}$, Sutinah Made ${ }^{2}$, Hamzah Tahang2 ${ }^{2}$, Andi Adri Arief ${ }^{2}$, Jamaluddin Jompa ${ }^{3}$, Rahim Darma ${ }^{3}$, Sitti \\ Nurani Sirajuddin ${ }^{3}$
}

\author{
${ }^{1}$ Agribusiness Study Program Students, Postgraduate School of Hasanuddin University, Indonesia \\ ${ }^{2}$ Lecturer of Fisheries Department of Hasanuddin University, Indonesia \\ ${ }^{3}$ Lecturer of Agribusiness Program, Postgraduate School of Hasanuddin University, Indonesia
}

Correspondence Author: Asriani. Students of the Graduate Studies Program in Agribusiness at the University of Hasanuddin. Indonesia E-mail: asriani2504@yahoo.com

Received date: 29 August 2019, Accepted date: 28 October 2019, Online date: 30 October 2019

Copyright: (c) 2019 Asriani et al. This is an open-access article distributed under the terms of the Creative Commons Attribution License, which permits unrestricted use, distribution, and reproduction in any medium, provided the original author and source are credited.

\section{Abstract}

Sea cucumbers are fishery commodities that have good prospects to be developed because of high economic values. Demand sea cucumbers mainly for export each year continues to increase. In the South Sulawesi area famous as a center of business, namely Takalar, Selayar and Barrang Lompo. There are many entrepreneurs' cucumbers implement agribusiness is not optimal, the use of tools of unsafe fishing line with KP PERMEN No.PER.02/MEN/2011 regarding fishing lines and the placement of the API and the ABPI in WPPNRI. The study was conducted in South Sulawesi with respondent as 44 people with locations in Barrang Lompo, Takalar, Selayar. Data were analyzed using analysis of financial feasibility, SWOT, QSPM. The results showed that the business financially with positive NPV and a screen, but it is technically not feasible because they use diving equipment unsafe and likely to cause paralysis/death. internal factors (strengths:the availability of sea cucumbers in the sea, the business profitable and weaknesses: compressor does not meet safety standards, lack of government attention) while external factors (export demand is high, increase foreign exchange the occurrence of paralysis). Do strategic priorities is to optimize the catch, reliable certified diver, dried quality improvement, oversight of business activities, provide education on cultivation.
\end{abstract}

Keywords: Cucumber, agribusiness, Feasibility, Strategy

\section{INTRODUCTION}

Indonesia is one country that is rich in sea urchins, sea cucumbers in the world's largest producer. Based on data from the UN Food and Agriculture Organization (FAO) in 2000, Indonesia is the biggest producer of sea cucumbers in the world (about 2,500 tons), there are 32 species of sea cucumbers. Cucumbers can be processed into food and traded in various forms in the form of food supplement products, cosmetics and drug products are efficient for the treatment of multiple diseases [5, 9]. Data from the Ministry of Maritime Affairs and Fisheries throughout the year 2012-2016 shows trends in exports of sea cucumbers has increased from 900 to 2.300 tons/year. As for China, Singapore and Taiwan remain a significant customer. Demand sea cucumbers, mainly for export, has been increasing every year so that fishing and hunting at sea take place more intensively causes a decrease in the catch from the sea [1].

Sea cucumber fishery commodity has good prospects and high economic value, both in local and international markets. According to the research, high nutrient content of sea cucumbers, that in dry conditions consisted of $82 \%$ protein, $1.7 \%$ fat, $8.9 \%$ moisture content, ash content of $8.6 \%$, and $4.8 \%$ carbohydrate. This is what makes high value-selling sea cucumbers [2, 5].

In South Sulawesi, the price of cucumbers ranged from Rp150,000 / kg to Rp2,300,000 / kg. Sea cucumbers have been trafficked and are exported to China since the 17th century. Sea cucumber hunting by sailors Bugis Makassar in northern Australia has been going on since the 17th century and ended in 1910 [6]. After that, the arrest operation areas cover only South Sulawesi and the surrounding waters. The production decline is because the sea cucumber wild population declined, so not worth the price increases and demand from export markets. To meet the export market, one of the paths taken by entrepreneurs in South Sulawesi is to catch on the high seas with diving using sophisticated equipment or by using a Mini trawl net fishing gear (3)

In the province of South Sulawesi with locations in Barrang Lompo, Takalar and Selayar, there is a lot involved in sea 
cucumber with implementing agribusiness system is not optimal. The influence of internal and external factors and so it takes an optimal agribusiness development strategy. The purpose of this research is (i) to analyze the financial feasibility of developing agribusiness sea cucumbers, (ii) to analyze the internal factors and external, and (iii) to analyze the development strategy of sea cucumbers (Holothuroidea sp) agribusiness in South Sulawesi in Indonesia.

\section{METHODOLOGY}

This research was conducted in the province of South Sulawesi, with locations in Barrang Lompo, Takalar and Selayar research carried out for 3 months starting in July-October 2019. This study examines the prospects for the development of agribusiness trepang (Holothuroidea) in the province of South Sulawesi.

Analysis of the data used in this study are

a. analysis descriptive to determine the agribusiness system, a SWOT analysis to assess the effect of internal and external factors, QSPM analysis to determine the priority strategies that can be done to solve the existing problems, as well as quantitative analysis using financial analysis

B. Quantitative analysis is used to calculate Business economic feasibility of sea cucumbers

To determine the feasibility of the business. The data analysis method used is the Present Net Value (NPV), Internal Rate of Return (IRR), Net Benefit-Cost Ratio (Net B / C Ratio) and Payback Period (PP)

1. Net Present Value (NPV) is the difference between income and expenditure has been completely absent, formulated:

Criteria if NPV $>0$, this $\quad \mathrm{NPV}=\sum_{\Delta t=1}^{-\frac{B t}{(1}+C_{t}}$

2. IRR is the interest that can be achieved, formulated:

IRR $=i_{1}+\frac{\mathrm{NPV}_{1}}{\left(\mathrm{NPV}_{1}-\mathrm{NPV}_{2}\right)} \times\left(\mathrm{i}_{2}-\mathrm{i}_{1}\right)$ business is feasible [7]

rate that indicates a project's ability to generate a profit level

Criteria if the IRR is greater than the prevailing bank interest rate (IRR> DR), a good business [6]

3. Net B / C aims to determine how much profit as compared to an expense over the economic life of the project, formulated (6), namely:

$$
\text { Net } \mathrm{B} / \mathrm{C}=\frac{\frac{\sum_{t=1}^{n} \mathrm{D}^{t}-r t}{(1+i)^{t}}}{\frac{\sum_{t=1}^{n} C t-B t}{(1=i)^{t}}} \rightarrow \frac{[}{\left[\frac{B t-C t>0]}{B t-C t<0]}\right.}
$$

if Net B / C> 1, the business is viable.

4. Payback Period is the period required to refund all expenses incurred, formulated [7], namely:

payback period $=$ I_ $\mathrm{x} 1$ year

Criteria, the business is feasible to run if the PP business is not too close to the end / longer than the life business [7]

\section{RESULTS AND DISCUSSION}

A. descriptive analysis

1. Cucumbers agribusiness system

Agribusiness subsystem sea cucumbers in southern Sulawesi province includes the following activities:

S Subsystem providing the means of production (Upstream Agribusiness) Diversity unit consisting of arrest

1. Boats / Ships

Fishing gear and equipment used include kerosene lamp 5 pieces, mask 5 pieces, 5 pieces of sea flashlight, compressor, regulator and mask 3 pairs, interval $200 \mathrm{~m}$

2. Fishing gear and tools arrest

Catching cucumbers done by hand by diving. Equipment used for diving among others mask 5 pieces, 3 pairs of frog legs, kerosene lamps 5 pieces, 5 pieces of sea flashlight and using the tools of the compressor as a tool for the arrest is not permitted and is not of poverty, population, relationship, safety, the lack of knowledge about diving healthy so that they use the compressor without equipped with filters for morbidly many of them that no matter dg. State of his own body. For that issued regulation of the minister of marine and fishery No. PER/02/MEN/2011 on fishing line and placement fire and the prohibited on any size of vessel and arrest pathways [4].

3. Diver

Sea cucumber divers in South Sulawesi with locations in Selayar, Takalar and Barrang Lompo wear divers from the scuba divers from Madura, East Nusa Tenggara, Papua, Pangkep etc. method of preparation trip arrest operation started at $15.00 \mathrm{pm}$. Labour transporting gear and rations to the ship. At $15.30 \mathrm{pm}$ departure from the fishing base to the fishing ground. The arrest was made in an area designated waters, in Baranglompo catching sea cucumbers do in the Strait of Makassar, Sorong, Flores Sea and Borneo. Takalar arrest was made in Bone, Mamuju, Kendari, Sorong and Kalimantan at a screen while the arrest was made in the Flores Sea and Pangkep.

In the process of catching sea cucumbers at sea by divers should diver must first be given the knowledge and training on the procedures dives were good and safe as well as risks arising from diving unsafe, besides in recruitment and divers should employers cucumbers select based on ability and owned diver certificate to avoid things that are not desirable as paralysis and deatsh [8]. 


\section{Processing subsystem}

Dried sea cucumber produced quality than specified by the processing carried out is also determined by the quality of raw materials used Processing of the Dry Sea Cucumber

1. Cleaning: disembowelled first ripped open sea cucumber to cleanse the internal organs and then clean the sea cucumber with washed using clean water

2. Boiling: Boiling is carried out at least 15-30 minutes or when pressed meat had tasted chewy. Boiling is one of the traditional processing methods which aim to extend the shelf life of a product

3. Soaking or salting: immersion performed for about 15 minutes. Then boiled again and boiling sea cucumbers do only a few minutes, not during the time of the first boiling

4. Fumigation: fumigation process aims to reduce the water content in the sea cucumber. This process takes about 30 minutes

5. The drying and drying: If the weather is hot can be done in just 3 days, but if the weather is cloudy or rainy season so the drying process requires a longer time. The drying aims to eliminate the water content in sea urchins, sea cucumbers make it more durable

6. Weighing and Storage: Dry Sea Cucumber is deposited or sold large companies or exporters. After that employer in Barrang Lompo sea cucumbers, sea cucumbers Takalar and Selayar store them in a basket or box until sufficient numbers for sale

Downstream subsystem

In this section assessed on the storage and packaging of dried sea cucumbers to then be marketed. The packing process is done by weighing the first and then enter the sea cucumbers into a box that had been prepared to then be transported to the sale of sea cucumbers

$>$ subsystem Marketing

The main marketing objectives dried sea cucumber at the study site is a great company and the export market. Although marketing in the country of considerable potential but limited commodity consumers of sea cucumbers in the upper-middle-class

$>$ Infrastructures supporting subsystems

Of the few respondents to borrow capital to private banks such as Bank Danamon and Cooperation in the area, because they could be given the bank capital loans without collateral and can borrow money as venture capital in large numbers

\section{Feasibility Analysis of Sea Cucumber}

Sea cucumber business conditions in the province of South Sulawesi illustrates that the business is positive so it deserves to be developed, Barrang lompo is the location with the greatest feasibility level since gained an average rate of profit of IDR 586026847 then Takalar Rp 493975413 and Selayar IDR 388066 997. An attempt was declared eligible if the total fees received benefits exceed the costs, or in other words, if the NPV is more significant than zero, means the benefits that arise higher than the costs incurred thus eligible to run the business of sea cucumbers.

IRR shows the average annual internal rate of profit over the life of a business venture. Investing can be said to be feasible if it has the IRR greater than the opportunity cost of its capital (OCC). An IRR reflects the maximum interest rate that can be paid for by a business activity for the resources used. IRR calculation results in the business of sea cucumbers in southern Sulawesi province viable because it has the IRR exceeds the discount rate is determined as the research proceeds, which amounted to $32.67 \%$ ditakalar in Barrang Lompo diselayar by $30.65 \%$ and amounted to $30.29 \%$ IRR amount of the sea cucumber businesses due to investment costs are relatively small when compared to the benefits received during the life of the project so that the business of sea cucumbers are eligible to run.

Net $B$ / C ratio is the ratio between the net benefits are positive with negative net profits. In other words, the net benefits that benefit a business activity generated against anyone unit losses of the business. This analysis aims to determine how much acceptance compared with expenditures over the life of the business activities. Investment activity is feasible if Net B / C is greater than one. The results of calculation of Net B / C ratio on the business of sea cucumbers in South Sulawesi Province viable because each has its Net B / C ratio of more than 1. The figure shows that each cost IDR 1 spent will yield benefits in the effort respective sea cucumber Takalar IDR 1.59 at 1.43 and Barrang Selayar Lompo of 1.39. Value Net B / C> 1 then the sea cucumber business feasible.

Pay Back Period or the time needed to recoup the investment planted on business respondents indicate that in Takalar sea cucumbers, payback period of the loan faster is approximately 1 year and 3 months, the value of PP is lower than the maximum age is 3 years technical investment. While respondents in Selayar rate of return on capital for longer, which is about 1 year and 8 months. PP value not too long nearing the end of a payback.

\section{SWOT analysis}

Determining the direction of the development strategy with the SWOT method is based on internal factors consist of strength (strength) and weaknesses (weaknesses) that directly affect business operations. External factors include of chance (opportunity) and threats (threat) that helped influence the development of the sea cucumber fishery in southern Sulawesi province[10].

\section{$>$ Internal Strategy Factors Matrix}

Results identification the power factor (Strength) and the factor of weakness (Weakness) in agribusiness further cucumbers arranged in a Table IFAS (Internal Factors Analysis Summary) to formulate internal factors that can be used in the preparation of the policy strategy. IFAS matrix weighted results and the rating scale internal and external factors can be seen in the following table: 
Table 1. Matrix Internal Strategic Factors Analysis Summary (IFAS)

\begin{tabular}{lllc}
\hline Internal factors & Weight & rating & Score \\
Strengths (Strengths) & & 3 & $0: 26$ \\
\hline The availability of resources & $0: 09$ & 3 & $0: 39$ \\
Availability of driver from outside the area & $0: 13$ & 4 & $0: 52$ \\
Sea cucumbers have a higher selling price & $0: 13$ & 3 & $0: 26$ \\
Financially reweding & $0: 09$ & 3 & $0: 26$ \\
Easy processing method results & $0: 09$ & & \\
\hline Weaknesses (Weaknesses) & & 2.5 & $0: 33$ \\
\hline Capture tool not according to standards & $0: 13$ & $0: 17$ \\
Remote capture site & $0: 09$ & 2 & $0: 17$ \\
A long time at sea & $0: 09$ & 1.5 & $0: 10$ \\
\hline HR quality still low & $0: 07$ & 2.5 & $0: 27$ \\
Lack of government attention & $0: 11$ & & 2.74 \\
\hline Total & 1 & & \\
\hline
\end{tabular}

Source: Primary Data Processed After 2019

Based table 1 can be seen that the total score of 2.74 IFAS these values are above the average value that is equal to $2.5 \mathrm{so}$, it can be seen that the internal condition of the sea cucumber fishery businesses in the province of South Sulawesi dominated force that can encourage the development of enterprises so that agribusiness sea cucumber eligible to run

\section{$>$ Matrix Strategy External Factors}

Table 2. Matrix Strategic External Factors Analysis Summary (EFAS)

\begin{tabular}{llll}
\hline External factors & Weight & rating & Score \\
\hline Opportunity (opportunity) & & & \\
\hline High export demands each year & $0: 33$ & 4 & $1: 33$ \\
Expand employment in fisheries & $0: 11$ & 3 & $0: 33$ \\
Increasing foreign exchange & $0: 06$ & 3 & $0: 17$ \\
\hline The threat (threat) & & & \\
\hline The occurrence of illegal fishing & $0: 23$ & 2 & $0: 47$ \\
High export tax of sea cucumbers & $0: 13$ & 1 & $0: 12$ \\
Paralysis/ fatalities & $0: 14$ & 2 & $0: 28$ \\
\hline Total & $1: 00$ & & 2.70 \\
\hline
\end{tabular}

Source: Primary Data Processed After 2019

EFAS total score of 2.70. The total value exceeds the average limit value of 2.5 which means that the activities of fishing effort cucumbers able to respond to external factors because the more significant opportunities in the development of sea cucumber cucumbers so good business to be developed and be eligible to run.

Table 3. Matrix SWOT Analysis

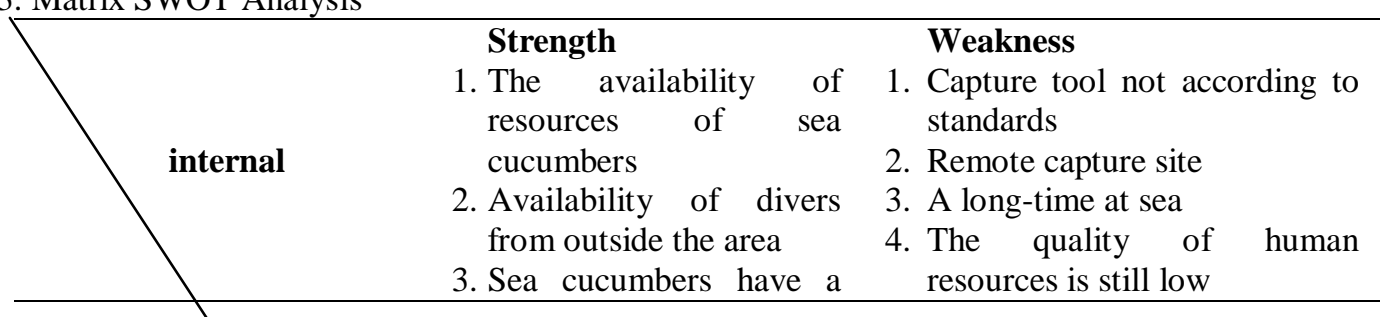




\begin{tabular}{|c|c|c|}
\hline External & $\begin{array}{l}\text { higher selling price } \\
\text { 4. Financially rewarding } \\
\text { 5. Easy processing method } \\
\text { results }\end{array}$ & $\begin{array}{l}\text { 5. Lack of attention to } \\
\text { government and related } \\
\text { agencies }\end{array}$ \\
\hline 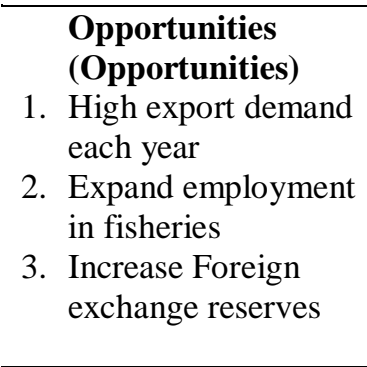 & $\begin{array}{l}\text { Strategy } \mathbf{S}><\mathbf{O} \\
\text { 1. Optimize catches of sea } \\
\text { cucumbers (I) } \\
\text { 2. Optimizing reliable } \\
\text { certified divers (II) } \\
\text { 3. Fixing processing } \\
\text { techniques to improve } \\
\text { the quality of sea } \\
\text { cucumbers (III) }\end{array}$ & $\begin{array}{l}\text { Strategy } \mathbf{W}><\mathbf{0} \\
\text { 1. HR Quality Improvement (IV) } \\
\text { 2. Increase cooperation with the } \\
\text { government and relevant } \\
\text { agencies (V) }\end{array}$ \\
\hline $\begin{array}{l}\text { Threats (Threats) } \\
\text { 1. The occurrence of } \\
\text { illegal fishing } \\
\text { 2. The high export tax of } \\
\text { sea cucumbers } \\
\text { 3. Paralysis/fatalities }\end{array}$ & $\begin{array}{l}\text { Strategy } \mathbf{S}><\mathbf{T} \\
* \quad \text { Provide Guidance } \\
\text { importance } \\
\text { restocking or cultivating } \\
\text { sea cucumber }(\mathrm{VI})\end{array}$ & $\begin{array}{l}\text { Strategy W> }<\mathbf{T} \\
\text { 1. Sea cucumber fishery } \\
\text { surveillance operations } \\
\text { (VII) } \\
\text { 2. The use of equipment } \\
\text { and tools safe diver } \\
\text { (VIII) }\end{array}$ \\
\hline
\end{tabular}

\section{Source: Primary Data Processed After 2019}

SWOT matrix based on the table above it can be seen that there are several strategies that can be undertaken by entrepreneurs sea cucumbers to expand its business in the face of competition in the future

\section{4. prospects for Development}

Priority development strategy Ranked strategy in order to obtain the list of priorities was done by using a quantitative strategy planning matrix (QSPM). This technique is intended to show the best alternative strategy in the development of sea cucumber fishing business in the province of South Sulawesi. QSPM detailed matrix are presented in the following table:

Table 4. Quantitative Strategic Planning Matrix Management (QSPM)

\begin{tabular}{|c|c|c|c|c|c|c|c|c|c|c|c|c|c|}
\hline \multirow{3}{*}{ Factor } & \multirow{3}{*}{ Weight } & \multicolumn{12}{|c|}{ Alternative strategies } \\
\hline & & \multicolumn{2}{|c|}{ I } & \multicolumn{2}{|l|}{ II } & \multicolumn{2}{|l|}{ III } & \multicolumn{2}{|l|}{ IV } & \multicolumn{2}{|l|}{$\mathbf{V}$} & \multicolumn{2}{|l|}{ VI } \\
\hline & & US & BAG & US & BAG & US & BAG & US & BAG & US & BAG & US & BAG \\
\hline \multicolumn{14}{|l|}{$S$} \\
\hline $\mathrm{S} 1$ & 0:09 & 3 & $0: 26$ & 3 & $0: 26$ & 3 & $0: 26$ & 3 & $0: 26$ & 4 & $0: 35$ & 3 & $0: 26$ \\
\hline $\mathrm{S} 2$ & $0: 13$ & 3 & $0: 39$ & 3 & $0: 39$ & 3 & $0: 38$ & 2 & $0: 26$ & 3 & $0: 39$ & 2 & $0: 26$ \\
\hline S3 & $0: 13$ & 4 & $0: 52$ & 2 & $0: 26$ & 2 & $0: 26$ & 2 & $0: 26$ & 1 & $0: 13$ & 2 & $0: 26$ \\
\hline $\mathrm{S} 4$ & 0:09 & 2 & $0: 17$ & 3 & $0: 26$ & 3 & $0: 26$ & 2 & $0: 17$ & 3 & $0: 26$ & 2 & $0: 17$ \\
\hline S5 & 0:09 & 2 & $0: 17$ & 3 & $0: 26$ & 3 & $0: 26$ & 1 & 0:09 & 2 & $0: 17$ & 1 & 0:09 \\
\hline \multicolumn{14}{|l|}{ W } \\
\hline W1 & $0: 13$ & 3 & $0: 39$ & 3 & $0: 39$ & 3 & $0: 39$ & 1 & $0: 39$ & 1 & $0: 13$ & 3 & $0: 39$ \\
\hline W2 & 0:09 & 3 & $0: 26$ & 2 & $0: 17$ & 2 & $0: 17$ & 2 & $0: 17$ & 2 & $0: 17$ & 3 & $0: 26$ \\
\hline W3 & 0:09 & 2 & $0: 17$ & 1 & 0:09 & 2 & $0: 17$ & 2 & 0:09 & 2 & $0: 17$ & 2 & $0: 17$ \\
\hline W4 & 0:07 & 2 & $0: 13$ & 2 & $0: 13$ & 2 & $0: 13$ & 2 & $0: 13$ & 2 & $0: 13$ & 1 & 0:07 \\
\hline \multirow[t]{2}{*}{ W5 } & $0: 11$ & 3 & $0: 33$ & 1 & $0: 11$ & 3 & $0: 33$ & 3 & $0: 33$ & 3 & $0: 33$ & 3 & \\
\hline & & & & & & & & & & & & & $0: 33$ \\
\hline \multicolumn{14}{|l|}{$\mathrm{O}$} \\
\hline $\mathrm{O} 1$ & $0: 23$ & 3 & 0.69 & 2 & $0: 46$ & 2 & $0: 46$ & 3 & 0.69 & 3 & 0.69 & 2 & $0: 46$ \\
\hline $\mathrm{O} 2$ & $0: 23$ & 4 & 0.92 & 2 & $0: 46$ & 3 & 0.69 & 2 & $0: 46$ & 1 & $0: 23$ & 2 & $0: 46$ \\
\hline $\mathrm{O} 3$ & $0: 15$ & 3 & $0: 46$ & 3 & $0: 46$ & 2 & $0: 31$ & 3 & $0: 46$ & 3 & $0: 46$ & 3 & $0: 46$ \\
\hline \multicolumn{14}{|l|}{$\mathrm{T}$} \\
\hline $\mathrm{T} 1$ & $0: 15$ & 2 & $0: 31$ & 2 & $0: 31$ & 1 & $0: 15$ & 1 & $0: 15$ & 3 & $0: 46$ & 3 & $0: 46$ \\
\hline $\mathrm{T} 2$ & 0:08 & 1 & 0:08 & 3 & $0: 23$ & 1 & 0:08 & 2 & $0: 15$ & 1 & 0:08 & 2 & $0: 15$ \\
\hline T3 & $0: 15$ & 2 & $0: 31$ & 3 & $0: 46$ & 2 & $0: 31$ & 3 & $0: 46$ & 2 & $0: 31$ & 2 & $0: 31$ \\
\hline Total & & & $5: 57$ & & 4.71 & & 4.63 & & & & $4: 47$ & & $4: 57$ \\
\hline 1 & & & & 2 & & 3 & & 5 & & 6 & & 4 & \\
\hline
\end{tabular}


From table 4, QSPM results show that the strategy is a top priority with a value of 5.57 is the first strategy that optimizes business and commodity market potential of sea cucumbers. Priority strategy TAS arranged in order of highest to lowest value. The resulting strategic priorities QSPM matrix is:

1. Optimizing the catch of sea cucumbers in the sea. Optimization strategies in the utilization of sea cucumber resources are needed for longer-term utilization. The need for cooperation with other regions, in addition to companies in Surabaya to increase local marketing.

2. Optimizing certified reliable divers, Improving the quality of human resources by providing counselling and coaching to sea cucumber entrepreneurs regarding the activities of catching sea cucumbers by divers and safe procedures when diving. Training on the latest capture fisheries technology can also be carried out to increase the knowledge of entrepreneurs and divers. In addition, the use of the equipment and the use of safe diving aids are the main factors for business continuity in the future.

3. Improve processing techniques to improve the quality and quality of dried sea cucumbers produced. Improving the quality of the manpower for processing by providing workers with good knowledge of how to process sea cucumbers properly and correctly to reduce the risk of product damage and large losses and to be able to meet export quality standards

4. Supervision of sea cucumber fishery business activities, Routine supervision related to sea cucumber fishing activities by local service officers needs to be done. This activity is useful in administrative records of catch productivity data obtained so that it has complete annual statistical data.

5. Increasing cooperation with the government and institutions related to the capital with banks and the government This cooperation is needed for the smooth operation and improvement of the business that has been run.

6. Providing counselling to sea cucumber entrepreneurs about the importance of restocking / good cultivation, ranging from land preparation, maintenance to harvest, although currently the sea cucumber business activities still produce large profits, the sea cucumber restocking, and cultivation program need to be carried out for the sake of sea cucumber sustainability and business sustainability.

\section{CONCLUSIONS AND RECOMMENDATIONS}

The conclusions from the results and discussion are as follows:

1. The sea cucumber agribusiness system is carried out in stages: providing production advice, processing subsystems, downstream subsystems, marketing subsystems and supporting facilities/infrastructure subsystems

2. The results of the financial feasibility analysis show that the sea cucumber agribusiness is feasible to run with a Barrang NPV value of Rp. 586,026,847, Takalar 493,975,413 and selayar 388,066,997.

3. Internal factors of sea cucumber business are the availability of sea cucumber resources, labour, profitable business, simple equipment, easy processing methods, fishing equipment that is not in accordance with the standard, location and long sea time, results of processing are not according to standards while external factors that influence are : high export demand, expanding employment, increasing sales, business competition

4. Strategy priorities based on the QSPM matrix are Optimizing business and market potential, optimizing reliable workforce, Improving the quality of human resources, Supervising sea cucumber fishery business activities, Increasing capital cooperation and Providing counselling.

\section{REFERENCES}

1. Akmal. 2015. Fisheries Statistics of the Department of Fisheries and Maritime Affairs of South Sulawesi Province. Makassar

2. Ardianingtyas, IA 2013 Sea cucumber fisheries business and its development in the Thousand Islands, DKI Jakarta Province. Thesis. Faculty of Fisheries and Marine Sciences Bogor Bogor Agricultural University

3. Brackish Aquaculture and Fisheries Extension Research Center, 2016. South Sulawesi

4. Directorate of Biodiversity and Marine Conservation. Director General of Marine Space Management. 2015. National Action Plan for Sea Cucumber Conservation. Jakarta. Period 1: 2016-2020. 24 pages

5. Ratna and Amir M. Suruwaky. 2016. Feasibility Analysis of Sea Cucumber (Holothuroidea) Business in Samate District, Raja Ampat Regency. Airaha Journal. ISSN: 2130-7163 vol.5. Number 1.11) Sorong Muhammadiyah University 2) Sorong Marine and Fisheries Polytechnic.

6. Suwardi Tahe, 2013, Present Status of Sea Cucumber Production and Aquaculture in South Sulawesi. Proceedings of the Aquaculture Technology Innovation Forum. 
7. Syarif, K. 2011. Business Feasibility Analysis of Brand Aromatic Oil Products Flosh Thesis: Bogor Agricultural University, Bogor. Pages 11-12.

8. Yanti, M.P.N., N.J. Subagio, and Wiryanto, J. 2014. Types and Density of Sea Cucumbers (Holothuroidea) in South Bali Waters. Symbiosis. 2 (1): 158-171 p Ministry of Maritime Affairs and Fisheries. 2018. Fisheries Export Volume Report. Jakarta

9. Yusron E., 2004. Sea cucumber Resources in Tanjung Pai Padaido Biak Numfor Papua. 8 (3): 123-127

10. Rangkuti, 2016. SWOT Analysis of Techniques for Dissecting Business CASE. PT. Gramedia Pustaka Utama, Jakarta 